\title{
Combined effect of titanium particles and TNF- $\alpha$ on the production of IL-6 by osteoblast-like cells
}

\author{
Hiroshi Takei, ${ }^{1}$ Dominique P. Pioletti, ${ }^{2}$ Soon Yong Kwon, ${ }^{1}$ K.-L. Paul Sung ${ }^{1-3}$ \\ ${ }^{1}$ Department of Orthopaedics, University of California, San Diego, 9500 Gilman Drive, La Jolla, California $92093-0412$ \\ ${ }^{2}$ Department of Bioengineering, University of California, San Diego, California \\ ${ }^{3}$ The Whitaker Institute of Biomedical Engineering, University of California, San Diego, 9500 Gilman Drive, \\ La Jolla, California 92093-0412
}

Received 30 April 1999; accepted 22 March 2000

\begin{abstract}
To clarify the role of tumor necrosis factor (TNF) $-\alpha$ on osteoblast functions in the presence of metal particles, two human osteoblast-like cell lines (MG-63 and SaOS-2) were cultured with TNF- $\alpha$ in the presence or absence of titanium particles in vitro. A combination of TNF- $\alpha$ and titanium particles showed additive effects on inhibition of cell proliferation and alkaline phosphatase production. On the other hand, production of interleukin-6, which is well known to induce osteoclastogenesis and to directly stimulate bone resorption, was additively stimulated by the combination of TNF- $\alpha$ and titanium particles. These results suggest that the association of TNF- $\alpha$ and titanium particles
\end{abstract}

may play an important role in the pathogenesis of periprosthetic osteolysis through two different pathways: a reduced periprosthetic bone formation due to inhibition of osteoblast proliferation and alkaline phosphatase production, and osteoblast-mediated activation of osteoclastic bone resorption as suggested by the enhancement of interleukin-6 production. (C) 2000 John Wiley \& Sons, Inc. J Biomed Mater Res, 52, 382-387, 2000.

Key words: TNF- $\alpha$; Ti particles; osteoblast; IL-6; proliferation

\section{INTRODUCTION}

Periprosthetic osteolysis and implant loosening after joint arthroplasty in both cemented and cementless prostheses remain major causes of implant failure. One cause of implant loosening is the proliferation of a fibrous tissue surrounding the implant in which macrophages phagocytosed wear debris. ${ }^{1,2}$ Moreover, the interaction of particle wear debris with phagocytic cells results in the activation of cells which in turn produce mediators that provoke a cascade of osteolytic events. ${ }^{3-9}$ Among the osteolytic modulators, tumor necrosis factor (TNF)- $\alpha$ stimulates the osteoblasts to produce bone resorptive mediators, interleukin (IL)-6 and prostaglandin $\mathrm{E}_{2}\left(\mathrm{PGE}_{2}\right)^{7,10}$

The fibrous tissue also provides an excess of wear

Correspondence to: K.-L. Paul Sung; e-mail: klpsung@ bioeng.ucsd.edu

Contract grant sponsor: NIH; Contract grant number: AR 14918

Contract grant sponsor: OREF; Contract grant number: 59212A

(c) 2000 John Wiley \& Sons, Inc. particles in the periprosthetic space. ${ }^{11}$ Direct interactions between particles and bone cells are then possible. This fact is important because it has been shown that particles could influence the functions of osteoblasts. After osteoblast-like cells (MC3T3-E1) and rat osteosarcoma cells $(17 / 2.8)$ phagocytosed particles of hydroxyapatite, reduced cell growth and alkaline phosphatase activity were measured. ${ }^{12}$ Biosynthesis of both type-I and type-III collagen was decreased in the human osteoblast-like cell (MG-63) and human osteosarcoma cells, that had been treated with titanium (Ti) particles. ${ }^{13}$ Poly (methyl methacrylate) (PMMA) particles were also shown to inhibit osteoblast proliferation and collagen synthesis, whereas osteocalcin and IL-6 production were stimulated. ${ }^{14}$

Despite that the presence of wear particles in conjunction with cytokines seems a common trend in periprosthetic tissue, few data reflecting this situation are available for osteoblasts. We hypothesized that cytokines released by macrophages may alter the functional modulation of osteoblastic cells caused by wear particles. We then investigated the effect of TNF- $\alpha$, a representative cytokine released by macrophages, on osteoblast-like cell functions in the presence or ab- 
sence of Ti particles in vitro. We showed that TNF- $\alpha$ and Ti particles have additive effects on the inhibition of osteoblast proliferation and alkaline phosphatase (ALP) production. This additive stimulation in osteoblast was also measured for the production of IL-6, which is well known to induce osteoclastogenesis and to directly stimulate bone resorption.

\section{MATERIALS AND METHODS}

\section{Cells}

Human osteoblast-like cell lines MG-63 and SaOS-2 (American Type Culture Collection, Rockville, MD) were grown in Dulbecco's modified eagle's medium (Irvine Scientific, Santa Ana, CA) supplemented with $10 \%$ fetal bovine serum (Irvine Scientific), L-glutamate (4 mM), penicillin (100 $\mathrm{U} / \mathrm{mL})$, streptomycin $(100 \mu \mathrm{g} / \mathrm{mL})$, and fungizone $(0.25 \mu \mathrm{g} /$ $\mathrm{mL}$ ) (Biowhittaker, Walkersville, MD), at $37^{\circ} \mathrm{C}$ and $5 \% \mathrm{CO}_{2}$ in a humidified atmosphere. These cell lines display typical phenotypes of osteoblasts as the polygonal morphology, the formation of calcium phosphate salts, the production of alkaline phosphatase, the formation of calcium phosphate salts, or the production of osteocalcin when these cells are cultured with vitamin $\mathrm{D}_{3}{ }^{15-18}$

\section{Titanium particles}

Commercially pure Ti particles (-325 mesh) purchased from Sigma-Aldrich Chemicals (Milwaukee, WI) were sterilized by autoclave at $135^{\circ} \mathrm{C}$ for $15 \mathrm{~min}$. A semiautomatic image processing (NIH image software) of particles using optical microscopy allowed us to determine that $80 \%$ of the particles had a diameter smaller than $5 \mu \mathrm{m}$ (diameter ranged from 0.1 to $50 \mu \mathrm{m})$. After sterilization of the Ti particles, culture medium was added, followed by ultrasonication for $30 \mathrm{~min}$ immediately before use to minimize particulate aggregation. A $1 \%$ (wt \%) suspension as well as appropriate dilutions of Ti particles in medium described under "Cells" were used in the experiments with cells.

\section{TNF- $\alpha$}

Recombinant human TNF- $\alpha$ was purchased from Sigma (St. Louis, MO). The range of concentrations used (0-100 $\mathrm{ng} / \mathrm{mL}$ ) was based on previous reports ${ }^{19-23}$ and preliminary experiments in which TNF- $\alpha$ concentrated at less than 0.1 $\mathrm{ng} / \mathrm{mL}$ showed little effect on the proliferation of the osteoblast-like cells.

\section{Proliferation assay}

Alliquots $(50 \mu \mathrm{L})$ of MG-63 and SaOS-2 cell suspensions (5 $\times 10^{4} / \mathrm{mL}$ and $8 \times 10^{4} / \mathrm{mL}$, respectively), were seeded onto a 96-well plate, followed by incubation for $24 \mathrm{~h}$. Fifty microliters of variously concentrated TNF- $\alpha$ (for a final concentration of $0.1,1,10,25$, or $100 \mathrm{ng} / \mathrm{mL})$ or $25 \mu \mathrm{L}$ of TNF- $\alpha$ and $25 \mu \mathrm{L}$ of $\mathrm{Ti}$ particle solution (for a final solution of 0.004 , $0.016,0.063,0.250 \%$ for MG-63 and $0.001,0.004,0.016,0.063 \%$ for SaOS-2) were added and the culture was incubated for 72 h. For the experiments performed without Ti particles, the control group was the cells cultured without TNF- $\alpha$, whereas for the experiments performed simultaneously with TNF- $\alpha$ and Ti particles, the control group was the cells cultured without Ti particles. Cell proliferation was determined by a CellTiter 96® Aqueous One Solution Cell Proliferation Assay (Promega, Madison, WI). ${ }^{24}$ In this assay, a tetrazolium salt is converted into a formazane product, which is directly correlated with an absorbance reading at $520 \mathrm{~nm}$. The cell proliferation (\%) was defined by the absorbance of the supernatant of cells treated with $\mathrm{Ti}$ and/or TNF- $\alpha$ divided by the absorbance of the supernatant of cells not treated with $\mathrm{Ti}$ or TNF- $\alpha(\times 100)$. All results shown are one of the representative outcomes from at least four experiments with six replicates.

\section{ALP activity}

ALP activity was determined using an ALP kit (Diagnostic kit 245; Sigma) Because the levels of ALP in MG-63 cells are extremely low, only SaOS-2 cells were used. Cells were plated at $5 \times 10^{4}$ cells/well in 24-well culture plates with $0.5-\mathrm{mL}$ complete medium [medium described under "Cells" supplemented with $50 \mu \mathrm{g} / \mathrm{mL}$ ascorbic acid (Sigma) and 10 $\mathrm{m} M \beta$-glycerophosphate (Sigma)]. After $48 \mathrm{~h}$, the culture medium was replaced by fresh medium with or without 25 $\mathrm{ng} / \mathrm{mL} \mathrm{TNF}-\alpha$ and/or $0.032 \% \mathrm{Ti}$ particles. The control group was defined by the cells cultured without TNF- $\alpha$ and Ti particles. The cells were cultured for another $48 \mathrm{~h}$, then the medium was removed and the cells were rinsed three times with phosphate buffered solution followed by the addition of $0.5-\mathrm{mL}$ Triton-X 100 (1\%). After freezing and thawing, the cell lysates were sonicated for $1 \mathrm{~min}$ on ice. The cell lysates was centrifuged and a volume of $20 \mu \mathrm{L}$ of each sample was added to $100 \mu \mathrm{L}$ of $p$-nitrophenyl phosphate solution within a $96-$ well plate at $25^{\circ} \mathrm{C}$ and reacted for $3 \mathrm{~min}$. $p$-Nitrophenol is produced in the presence of ALP and the absorbance was measured at $405 \mathrm{~nm}$. The change in rate of absorbance is directly propotional to the ALP activity. Data were normalized for total cell protein measured with a commercial kit (DC protein assay kit; BioRad, Hercules, CA).

\section{IL-6 production}

IL-6 was assayed using an ELISA kit (Predicta IL-6 kit; Genzyme, Cambridge, MA). Cells were plated at $5 \times 10^{4}$ cells/well in a 24-well culture dish. After $48 \mathrm{~h}$, the culture medium was replaced by fresh media with or without 25 $\mathrm{ng} / \mathrm{mL}$ TNF- $\alpha$ and/or 0.125 or $0.032 \%$ Ti particles for MG-63 cells and SaOS-2 cells, respectively. The control group was the cells cultured without TNF- $\alpha$ and Ti particles. The cells 
were cultured for another $48 \mathrm{~h}$, then the medium was collected, centrifuged, and the levels of IL-6 determined. Data were normalized for total cell protein determined as described above.

\section{Statistical analysis}

Data are expressed as the mean \pm SEM. For the proliferation assays, a one-way analysis of variance (ANOVA) test was used to analyze the mean variance of cell proliferation. If significant differences were found, a Student's $t$ test was performed to determine which mean was different than mean of control. For the ALP and IL-6 assays, a two-way ANOVA test was used to analyze the effect of TNF- $\alpha, \mathrm{Ti}$ particles, and the possible additive effect of both. A 95\% confidence level was selected to define significance for all statistical tests.

\section{RESULTS}

\section{Particle-free medium test}

The 1\% Ti particle solution (without cells) was incubated for $72 \mathrm{~h}$, aspirated, and added (without particles) to cells. The cells cultured with this conditioned, particle-free medium had no effect on cell proliferation and the production of ALP IL-6 (data not shown). This excluded the possibility that $\mathrm{Ti}$ ions or soluble contaminants on the surface of particles could affect the cell functions.

\section{Cell proliferation}

Preliminary results showed that MG-63 and SaOS-2 cell proliferations were directly correlated with the absorbance values of the formazane product at $520 \mathrm{~nm}$ $\left(R^{2}=0.984\right.$ and 0.987 respectively, $\left.n=6\right)$. The absorbance values at $520 \mathrm{~nm}$ also correlated with the number of living cells, which were counted directly on a hemocytometer with trypan blue after co-culture with titanium particles (up to 1.0\%) and/or TNF- $\alpha$ (up to $100 \mathrm{ng} / \mathrm{mL}$ ) for $72 \mathrm{~h}$ (data not shown).

\section{Effect of TNF- $\alpha$ on cell proliferation}

Cell proliferation was statistically decreased by TNF- $\alpha$ concentrated at more than $0.1 \mathrm{ng} / \mathrm{mL}$ for MG63 (Fig. 1(a); $p<0.05$ ) and more than $10 \mathrm{ng} / \mathrm{mL}$ for SaOS-2 (Fig. 1(b); $p<0.05$ ) for $72 \mathrm{~h}$. All values were normalized by the control, TNF- $\alpha$-free, group.

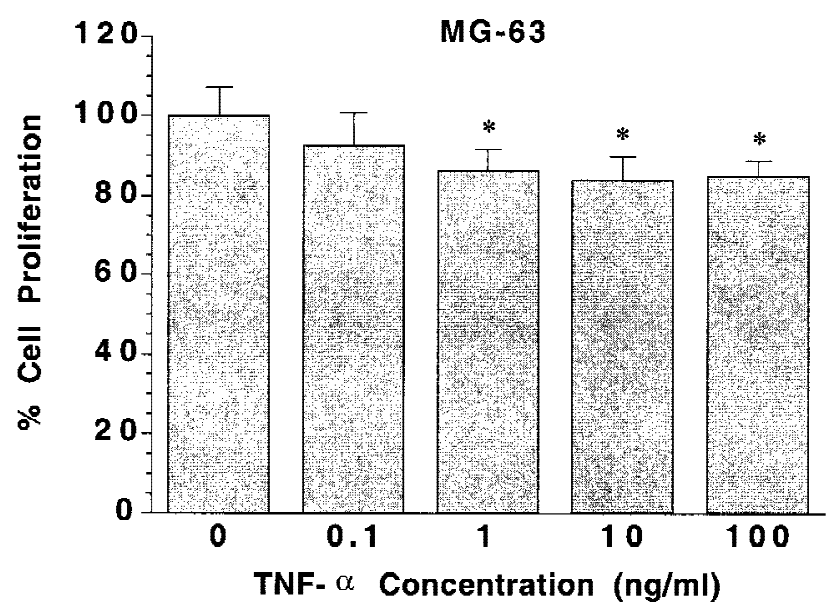

(a)

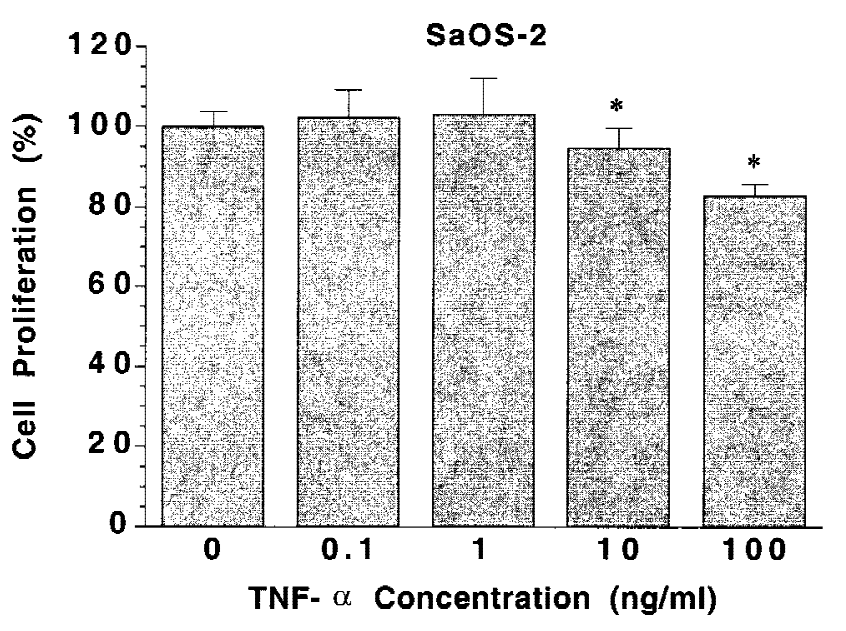

(b)

Figure 1. The effect of TNF- $\alpha$ on osteoblast like cells after $72 \mathrm{~h}$ of incubation. (a) MG-63 cells, (b) SaOS-2 cells, treated with various concentrations of TNF- $\alpha(0,0.1,1,10$, and 100 $\mathrm{ng} / \mathrm{mL}$ ). The results of proliferation versus concentration of TNF- $\alpha$ were plotted (mean \pm SEM, $n=6$ ). The data were normalized with respect to the control group $(0 \mathrm{ng} / \mathrm{mL}$ TNF- $\alpha$ ). ${ }^{*} p<0.05$ compared with control.

\section{Effect of TNF- $\alpha$ on cell proliferation in the presence of Ti particles}

Ti particles concentrated at $0.063 \%$ or more for MG63 [Fig. 2(A)] and at $0.016 \%$ or more for SaOS-2 [Fig. 2(b)] statistically decreased the cell proliferation $(p<$ 0.05 , for Fig. 2(a,b). The sensitivity of Ti particles was seen more in the proliferation of SaOS-2 than MG-63 cells. The addition of TNF- $\alpha$ concentrated at $25 \mathrm{ng} / \mathrm{mL}$ markedly increased this adverse effect induced by particles. Furthermore, the ratio of the inhibitory effect caused by TNF- $\alpha$, when compared with the TNF- $\alpha-$ negative group, increased as the concentration of the titanium particles increased; e.g., although $22 \%$ of the proliferation was decreased by TNF- $\alpha$ at $0 \mathrm{wt} \%$ of Ti particles, $36 \%$ of the proliferation was decreased by TNF- $\alpha$ in the presence of $0.250 \mathrm{wt} \%$ of Ti particles in 


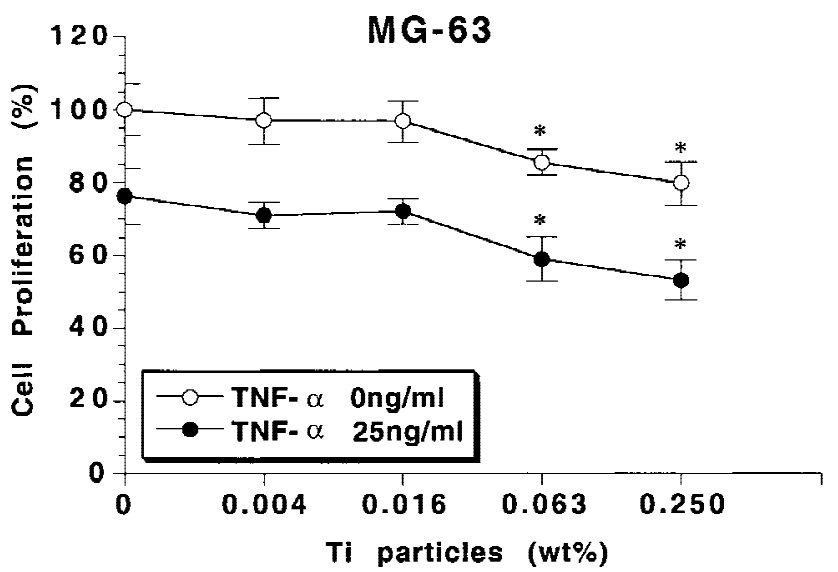

(a)

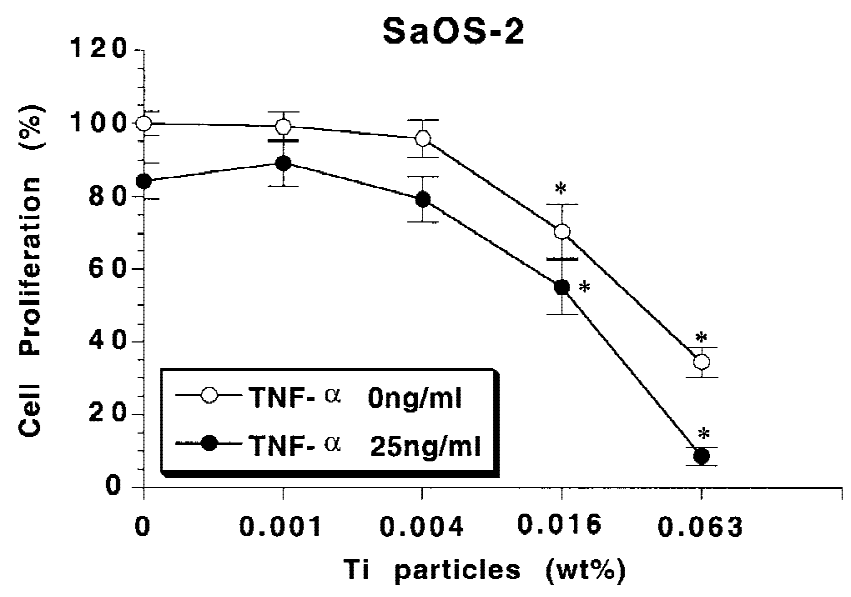

(b)

Figure 2. The effect of Ti particles and TNF- $\alpha$ on osteoblast-like cell proliferation after $72 \mathrm{~h}$ of incubation (mean \pm SEM, $n=6$ ). The data were normalized with respect to the proliferation obtained without Ti particle and TNF- $\alpha$. (a) MG-63 cells, (b) SaOS-2 cells. The concentrations of Ti particle (wt \%) used in the system are indicated on the horizontal axis. ${ }^{*} \mathrm{p}<0.05$ compared with control (without particles) in each group.

the MG-63 cell system [Fig. 2(a)]. In the SaOS-2 cell system [Fig. 2(b)], 77\% of the proliferation was decreased by TNF- $\alpha$ in the presence of $0.063 \mathrm{wt} \%$ of Ti particles, whereas $16 \%$ of the proliferation was decreased by TNF- $\alpha$ at 0 wt $\%$ of Ti particles.

\section{Effect of TNF- $\alpha$ and Ti particles on ALP activity}

ALP activity of SaOS-2 cells decreased when incubated with TNF- $\alpha$ concentrated at $25 \mathrm{ng} / \mathrm{mL}$. The combination of TNF- $\alpha$ and Ti particles $(0.032 \%)$ markedly decreased the ALP activity of SaOS-2 cells (Fig. 3). This additive effect of TNF- $\alpha$ and Ti particles was significantly relevant.

\section{Effect of TNF- $\alpha$ and Ti particles on IL-6 production}

IL-6 production by MG-63 cells cultured with TNF- $\alpha$ markedly increased when compared with the

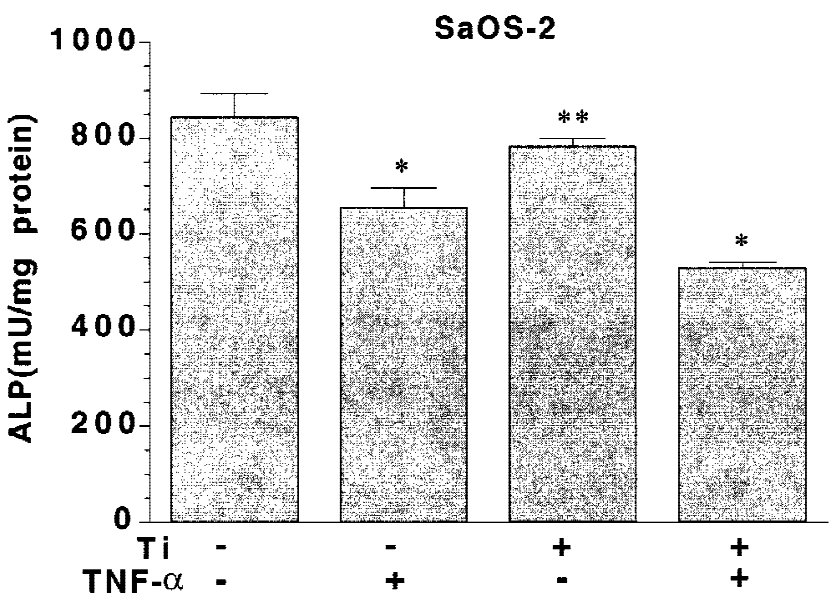

Figure 3. The effect of Ti particles $(0.032 \%)$ and TNF- $\alpha(25$ $\mathrm{ng} / \mathrm{mL}$ ) to ALP activity on SaOS-2 cells after $48 \mathrm{~h}$ of incubation (mean \pm SEM). " + " indicates the presence of corresponding stimulus, whereas "-" indicates its absence. Using a two-way ANOVA analysis, an additive effect of TNF- $\alpha$ and Ti particles on the ALP activity was demonstrated $\left({ }^{*} p<\right.$ $\left.0.001 ;{ }^{* *} p<0.042 ; n=3\right)$.

control (Table I). A statistically synergistic effect on IL-6 production by the MG-63 cells was measured when these cells were incubated with a combination of Ti particles and TNF- $\alpha$. IL-6 production from SaOS-2 cells was only detected when incubated with TNF- $\alpha$. However, Ti particles with TNF- $\alpha$ markedly increased the production of IL-6 by SaOS-2 cells.

\section{DISCUSSION}

Prostheses made of titanium alloys are extensively used for the management of joint disorders. Although in vitro studies have revealed that Ti particles are less toxic than $\mathrm{Co}-\mathrm{Cr}$ particles, ${ }^{25,26}$ titanium alloys have a certain premature failure rate $e^{27,28}$ suggesting that debris from titanium prostheses have harmful effects. One of the reasons for this may be the higher concentration of metal particles in tissue around loose titanium-alloy implants compared with those with loose implants made of other alloys. ${ }^{29-32}$ In our laboratory, we also found that Ti particles have harmful effects on the viability of neonatal rat calvarial osteoblasts in a dose-dependent manner. ${ }^{33}$

In the present study, we investigated the in vitro effect of TNF- $\alpha$ on osteoblast functions in combination with $\mathrm{Ti}$ particles at concentrations representative of what can be found during biopsy studies. ${ }^{30}$ We have demonstrated that TNF- $\alpha$ and Ti particles have additive effects on inhibition of cell proliferation and decrease the production of ALP on human osteogenic cell-lines MG-63 and SaOS-2. Moreover, the production of IL-6, which is well known to induce osteoclastogenesis and to directly stimulate bone resorp- 
TABLE I

Levels (pg/mg Protein) of IL-6 Released by Osteoblastic Cells Stimulated by Titanium Particles with or without TNF- $\alpha$ for $48 \mathrm{~h}$

\begin{tabular}{lccccc}
\hline & \multicolumn{5}{c}{ Treatment } \\
\cline { 2 - 6 } Cells & Ti Particles $^{\mathrm{a}}$ & - & - & + & + \\
\hline TNF- $\alpha^{\mathrm{b}}$ & - & + & - & + \\
\hline MG-63 & & $103 \pm 13$ & $8128 \pm 410^{*}$ & $165 \pm 18^{* *}$ & $9542 \pm 512^{*}$ \\
Saos-2 & ND & $416 \pm 82$ & ND & $895 \pm 214$ \\
\hline
\end{tabular}

a Ti particles; $0.125 \%$ for MG-63 cells and $0.032 \%$ for Saos- 2 cells.

${ }^{\mathrm{b}} \mathrm{TNF}-\alpha$ : $25 \mathrm{ng} / \mathrm{mL}$.

ND, not detected.

Data are mean \pm SEM; $n=6$.

${ }^{*} p<0.007$.

${ }^{* *} p<0.013$.

tion, ${ }^{20,34,35}$ was additively stimulated. In vitro studies aiming to quantify the reaction of bone cells to particles should then also be concerned with the possible modulation by cytokines that would be present in the corresponding in vivo situation.

The data obtained with TNF- $\alpha$ are consistent with several other reports in which TNF- $\alpha$ inhibits ALP production but increases IL- 6 synthesis in osteoblastic cells. ${ }^{21-23}$ It has been suggested that TNF- $\alpha$ stimulates IL-6 production of osteoblastic cells by activation of transcription factor NF- $\mathrm{kB}$ : gene regulatory factor. ${ }^{23,36}$ It has also been reported that TNF- $\alpha$ regulates IL- 6 production of osteoblastic cells through sphingomyelin hydrolysis to produce sphingosine 1-phosphate as a second messenger and protein kinase $\mathrm{C}$ activation as an autoregulator. ${ }^{21}$

In a previous study, Chiba et al. ${ }^{19}$ showed that an approximately $5-\mathrm{mm}^{3}$ interface membrane retrieved from patients with loose cementless hip prostheses cultured with $2 \mathrm{~mL}$ of medium produced up to more than $9 \mathrm{ng}$ TNF- $\alpha$ per $\mathrm{g}$ of tissue in the culture medium. This concentration of TNF- $\alpha$ in the medium could be concentrated more in loco. Furthermore, the concentration of TNF- $\alpha$ up to $100 \mathrm{ng} / \mathrm{mL}$ used in the present study is similar to what has been used in previous reports in which the effect of TNF- $\alpha$ on the functions of the osteoblast-like cells was investigated. ${ }^{20-23}$

Using calcium phosphate cement particles and TNF- $\alpha$ at concentrations similar to the present study, no additive effect on viability was noted with osteoblasts obtained from neonatal Sprague-Dawley calvarial rat. ${ }^{37}$ Despite comparisons between results obtained with different cell lines, it could be assumed that viability of SaOS-2 and MG-63 cells would not be affected by $\mathrm{Ti}$ particles and TNF- $\alpha$ at the concentrations used in this study.

In conclusion, we showed that by combining TNF- $\alpha$ and $\mathrm{Ti}$ particles, the effects on osteoblastic cells in terms of decreased proliferation and ALP production, and increased IL-6 production, are additively enhanced. It could be hypothesized from these results that the exposure of osteoblasts to TNF- $\alpha$ in combina- tion with $\mathrm{Ti}$ particles could contribute to the pathogenesis of peri-implant osteolysis. Further in vivo investigations to clarify this hypothesis should be performed.

The authors thank John Kim for his technical assistance.

\section{References}

1. Goldring SR, Schiller AL, Roelke M, Rourke CM, O'Neill DA, Harris WH. The synovial-like membrane at the bone-cement interface in loose total hip replacements and its proposed role in bone lysis. J Bone Joint Surg Am 1983;65:575-584.

2. Schmalzried TP, Jasty M, Harris WH. Peripheral bone loss in total hip arthroplasty. J Bone Joint Surg Am 1992;74:849-863.

3. Glant TT, Jacobs JJ, Molna'r G, Shanbhag AS, Valyon M, Galante JO. Bone-resorption activity of particulate-stimulated macrophages. J Bone Miner Res 1993;8:1071-1079.

4. Glant TT, Jacobs JJ. Response of three murine macrophage populations to particulate debris: Bone resorption in organ cultures. J Orthop Res 1994;12:720-731.

5. Horowitz SM, Doty SB, Lane JM, Burstein AH. Studies of the mechanism by which the mechanical failure of polymethylmethacrylate leads to bone resorption. J Bone Joint Surg Am 1993;75:802-813.

6. Horowitz SM, Doty SB, Lane JM, Burstein AH. The interaction of the macrophage and the osteoblast in the pathophysiology of aseptic loosening of joint replacement. Calcif Tissue Int 1994; 54:320-324.

7. Horowitz SM, Purdon MA. Mediator interactions in macrophage/particulate bone resorption. J Biomed Mater Res 1995; 29:477-484

8. Jasty M, Smith E. Wear particles of total joint replacements and their role in periprosthetic osteolysis. Curr Opin Rheumatol 1992;4:204-209.

9. Pollice RF, Silverton SF, Horowitz SM. Polymethyl methacrylate-stimulated macrophages increase rat osteoclast precursor recruitment through their effect on osteoblasts in vitro. J Orthop Res 1995;13:325-334.

10. Haynes DR, Hay SJ, Rogers SD, Ohta S, Howie DW, Graves SE. Regulation of bone cells by particle-activated mononuclear phagocytes. J Bone Joint Surg Br 1997;79:988-993.

11. Malaval L, Modrowski D, Gupta AK, Aubin JE. Cellular expressing of bone-related proteins during in vitro osteogenesis in rat bone marrow stromal cell cultures. J Cell Physiol 1994; 158:555-572.

12. Alliot-Licht B, Gregoire M, Oray I, Menanteau J. Cellular ac- 
tivity of osteoblasts in the presence of hydroxyapatite: An in vitro experiment. Biomaterials 1991;12:752-756.

13. Yao J, Szabo GC, Jacob JJ, Kuettner KE, Glant TT. Supression of osteoblast function by titanium particles. J Bone Joint Surg Am 1997;79:107-112.

14. Zambonin G, Colucci S, Cantatore F, Grano M. Response of human osteoblasts to polymethylmetacrylate in vitro. Calcif Tissue Res 1998;62:362-365.

15. Franceschi RT, Romano PR, Park KY. Regulation of type I collagen synthesis by 1,25-dihydroxyvitamin D3 in human osteosarcoma cells. J Biol Chem 1988;263:18938-18945.

16. Stock JL, Coderre JA, DeVito WJ, Baker S. Effects of human lymphocyte-conditioned medium on MG-63 human osteosarcoma cell function. Cytokine 1998;10:603-612.

17. Rodan SB, Imai Y, Thiede MA, Wesolowski G, Thompson D, Bar-Shavit Z, Shull S, Mann K, Rodan GA. Characterization of a human osteosarcoma cell line (SaOS-2) with osteoblastic properties. Cancer Res 1987;47:4961-4966.

18. Yoshihara R, Shiozawa S, Imai Y, Fujita T. Tumor necrosis factor- $\alpha$ and interferon- $\gamma$ inhibit proliferation and alkaline phosphatase activity of human osteoblastic SaOS-2 cell line. Lymphokine Res 1990;9:59-65.

19. Chiba J, Rubash HE, Kim KJ, Iwaki Y. The characterization of cytokines in the interface tissue obtained from failed cementless total hip arthroplasty with and without femoral osteolysis. Clin Orthop 1994;300:304-312.

20. Kozawa O, Suzuki A, Kaida T, Tokuda H, Uematsu T. Tumor necrosis factor- $\alpha$ autoregulates interleukin- 6 synthesis via activation of protein kinase C. J Biol Chem 1997;272:25099-25104.

21. Kurihara N, Civin C, Roodman D. Osteotropic factor responsiveness of highly purified populations of early and late precursors for human multinucleated cells expressing the osteoclast phenotype. J Bone Miner Res 1991;6:257-261.

22. Kuroki T, Shingu M, Koshihara Y, Nobunaga M. Effects of cytokines on alkaline phosphatase and osteocalcin production, calcification and calcium release by human osteoblastic cells. Br J Rheumatol 1994;33:224-230.

23. Kurokouchi K, Kambe F, Yasukawa K, Izumi R, Ishiguro N, Iwata $H$, Seo $H$. TNF- $\alpha$ increases expression of IL-6 and ICAM-1 genes through activation of NF-кB in osteoblast-like ROS17/2.8 cells. J Bone Miner Res 1998;13:1290-1299.

24. Wang JY, Wicklund BH, Gustilo RB, Tsukayama DT. Titanium, chromium and cobalt ions modulate the release of bone associated cytokines by human monocytes/macrophages in vitro. Biomaterials 1996;17:2233-2240.

25. Haynes DR, Rogers SD, Hay S, Pearcy MJ, Howie DW. The differences in toxicity and release of bone-resorbing mediators induced by titanium and cobalt-chromium-alloy wear particles. J Bone Joint Surg Am 1993;75:825-834.

26. Rae T: A study on the effects of particulate metals of orthopedic interest on murine macrophages in vitro. J Bone Joint Surg Br 1975;57:444-450.

27. Lombardi AV, Mallory TH, Vaughan BK, Drouillard P. Aseptic loosening in total hip arthroplasty secondary to osteolysis induced by wear debris from titanium-alloy modular femoral heads. J Bone Joint Surg Am 1989;71:1337-1342.

28. Witt JD, Swann M. Metal wear and tissue response in failed titanium alloy total hip replacements. J Bone Joint Surg $\mathrm{Br}$ 1991;73:559-563.

29. Agins HJ, Alcock NW, Bansal M, Eduardo AS, Wilson PD Jr, Pellicci PM, Bullough PG. Metallic wear in failed titaniumalloy total hip replacements: A histological and quantitative analysis. J Bone Joint Surg Am 1988;70:347-356.

30. Brien WW, Salvalti EA, Betts F, Bullough $P$, Wright $T$, Rimnac C, Bully R, Garvin, K. Metal levels in cemented total hip arthroplasty: A comparison of well-fixed and loose implants. Clin Orthop 1992;276:66-74.

31. Hirakawa K, Bauer TW, Stulberg BN, Wilde AH, Secic M. Characterization and comparison of wear debris from failed total hip implants of different types. J Bone Joint Surg Am 1996;78:1235-1243.

32. Howie DW, Vernon-Roberts B. The synovial response to intraarticular cobalt-chrome wear particles. Clin Orthop 1988; 232:244-254.

33. Pioletti DP, Takei H, Kwon SY, Wood D, Kung KLP. The cytotoxic effect of titanium particles phagocytosed by osteoblasts. J Biomed Mater Res 1999;46:399-407.

34. Ishimi $\mathrm{Y}$, Miyaura $\mathrm{C}$, Jin $\mathrm{CH}$, Akatsu $\mathrm{T}$, Abe $\mathrm{E}$, Nakamura $\mathrm{Y}$, Yamaguchi A, Yoshiki S, Matsuda T, Hirano T, Kishimoto T, Suda T. IL-6 is produced by osteoblasts and induces bone resorption. J Immunol 1990;145:3297-3303.

35. Jilka RL, Hangoc G, Girasole G, Passeri G, Williams DC, Abrams JS, Boyce B, Broxmeyer H, Manolagas SC. Increased osteoclast development after estrogen loss: Mediation by interleukin-6. Science 1992;257:88-91.

36. Galien R, Evans HF, Garcia T. Involvement of CCAAT/ enhancer-binding protein and nuclear factor-kappa $\beta$ binding sites in interleukin-6 promotor inhibition by estrogens. Mol Endocrinol 1996;10:713-722.

37. Pioletti DP, Takei H, Lin T, Van Landuyt P, Ma QJ, Kwon SY, Sung KLP. The effects of calcium phosphate cement particles on osteoblast functions. Biomaterials, to appear. 